\title{
Effects of burn status and conditioning on colonization of wood by stream macroinvertebrates
}

\author{
Pedro G. Vaz ${ }^{1,6}$, Susana Dias ${ }^{1,7}$, Paulo Pinto ${ }^{2,8}$, Eric C. Merten ${ }^{3,9}$, Christopher T. Robinson ${ }^{4,10}$, \\ Dana R. Warren ${ }^{5,11}$, and Francisco C. Rego ${ }^{1,12}$ \\ ${ }^{1}$ CEABN-Centre of Applied Ecology "Prof. Baeta Neves"/InBIO-Research Network in Biodiversity and Evolutionary Biology, \\ Institute of Agronomy, University of Lisbon, Tapada da Ajuda, 1349-017 Lisbon, Portugal \\ ${ }^{2}$ Water Laboratory, Centre for Geophysics of Évora, University of Évora, Largo dos Colegiais, 7001 Évora codex, Portugal \\ ${ }^{3}$ Department of Biology, Wartburg College, Waverly, Iowa 50677 USA \\ ${ }^{4}$ Department of Aquatic Ecology, Eawag, 8600 Duebendorf, Switzerland and Institute of Integrative Biology, ETH-Zürich, Zürich, \\ Switzerland \\ ${ }^{5}$ Department of Fisheries and Wildlife, Oregon State University, Corvallis, Oregon 97331 USA
}

\begin{abstract}
The combination of changing climate and anthropogenic activities is increasing the probability of wildfire around the world. When fires occur in riparian zones, associated tree mortality can add wood directly to streams or wood may fall to the forest floor and remain there for some time before being transported into stream channels. Wood provides critical structure for aquatic macroinvertebrates, so our objectives were to assess the effects of wood burn status, conditioning, and their interaction on macroinvertebrate community composition, taxon and functional diversity, and trait affinities. We conducted a field experiment with pieces of freshly cut wood (length $=10 \mathrm{~cm}$, diameter $\approx 7.5 \mathrm{~cm}$ ) for which we first manipulated burn status (burned, unburned) and then, conditioned by placing burned and unburned wood directly into streams (no conditioning) or by leaving pieces in streams (water conditioning) or on the forest floor (soil conditioning) for a year before submergence. We used distance-based redundancy analysis to assess community structure by wood treatments and linear mixed-effects modeling to assess effects of wood treatments on taxon and functional diversity and trait affinity. Changes in wood quality resulting from fire may not alter macroinvertebrate community structure. Taxonomic and functional patterns of stream invertebrate colonization did not differ between burned and unburned wood, even after a year of incubation in the stream or on the forest floor. Conditioning status affected taxonomic composition, taxon and functional diversity, and trait affinities of wood invertebrate communities. The terrestrial legacy of soil conditioning was clearly important in structuring macroinvertebrate assemblages. Our results suggest that macroinvertebrate communities may be more sensitive to fire effects on the dynamics of wood input than to effects of fires on the wood itself.
\end{abstract}

Key words: wildfire, wood debris, wood condition, invertebrates, Portugal, traits, community structure

Changing climate and anthropogenic activities are synergistically increasing the probability of fire around the world (Moriondo et al. 2006, Flannigan et al. 2009, Moreira et al. 2011). As a consequence, the effects of fire disturbance on aquatic ecosystems have received increasing attention (Resh et al. 1988, Gresswell 1999, Romme et al. 2011, Verkaik et al. 2013). Forest wildfires promote recruitment of wood to aquatic ecosystems in many regions (Zelt and Wohl 2004, Arseneault et al. 2007, Jones and Daniels 2008, Vaz et al. 2011, 2013a, b).Wood from riparian trees may be injured by fire and then directly enter stream channels, or wood may fall to the forest floor and remain there until it moves laterally into stream channels during floods or from eroding banks. The mechanism by which wood enters the channel (i.e., directly or after some time on the forest floor) may affect the condition or quality of fire-derived wood for stream biota, such as benthic macroinvertebrates (Cummins and Klug 1979, Mihuc and Minshall 1995), but no investigators have examined the interplay between wood burn status and conditioning in structuring the composition and function of epidendric macroinvertebrate assemblages.

Wood can be characterized by its structural and chemical properties. Structure reflects bark type (e.g., looseness), holes, protrusions, grooves, small depressions, crevices, cracks, and availability of interstitial spaces (O'Connor

E-mail addresses: ${ }^{6}$ Present address: Department of Animal Science, University of California, Davis, California 95616 USA, pjgvaz@isa.ulisboa.pt; ${ }^{7}$ susanadias@isa.ulisboa.pt; ${ }^{8}$ ppinto@uevora.pt; ${ }^{9}$ eric.merten@wartburg.edu; ${ }^{10}$ robinson@eawag.ch; ${ }^{11}$ dana.warren@oregonstate.edu; ${ }^{12}$ frego@isa.ulisboa.pt 
1991, Mathooko and Otieno 2002). Chemically, wood has high $C: N$ and $C: P$ (relative to leaves) and large quantities of cellulose, lignocellulose, and lignin (Gulis et al. 2004). Bark can contain defensive compounds, such as polyphenols and terpenes (Sakai 2001, Gonçalves et al. 2007). The physical and chemical properties of wood are thermally degraded during fires $>300^{\circ} \mathrm{C}$. Bark is primarily affected and becomes loosely attached, softened, or removed. Charred wood results from incomplete combustion via surface oxidation in the form of smoldering (nonflaming) that depolymerizes cellulose. Char (black C) is chemically heterogeneous and biologically inert. Degradation of lignin occurs at $\sim 225$ to $450^{\circ} \mathrm{C}$, and at $\sim 450^{\circ} \mathrm{C}$ production of volatile compounds is complete. Water and extractants (namely lipids and terpenoid hydrocarbons) are lost from burned wood, but volatilization of repellent compounds (Schniewind 1989, Gama et al. 2007, Hyde et al. 2011) may make burned wood more attractive than unburned wood to colonizing organisms.

Soil conditioning and water conditioning differ in terms of fungal and bacterial colonization, but both precondition wood and facilitate colonization by organisms (Wong et al. 1998). In terrestrial environments, soil-conditioned wood decomposes relatively rapidly and decomposition is enhanced by fungi and to a lesser extent by bacteria. Brownand white-rot fungi are 2 major kinds of decay fungi. Brownrot fungi degrade cellulose and hemicellulose, whereas white-rot fungi degrade lignin and cellulose. Soft-rot fungi affect the outer surface of wood, especially in fissures under wet conditions (Bucher et al. 2004, FPL 2010). In water, microbial colonization of wood is a slow phenomenon that affects the surface of the wood (Harmon et al. 1986). Some fungi that colonize wood prior to submergence in water may survive and continue to produce fruiting bodies (Anderson et al. 1978). Within 2 wk, epixylic biofilms develop and coat the submersed wood, forming organic layers of fungi, bacteria, algae, extracellular polysaccharides, and trapped seston (Golladay and Sinsabaugh 1991, Couch and Meyer 1992). Most fungi in freshwaters carry out soft-rot on wood surfaces (Zare-Maivan and Shearer 1988), and basidiomycetes, which degrade lignin, are rare and usually absent.

Colonization of wood by stream macroinvertebrates is primarily a surface phenomenon, resulting from food and substrate affinities. Despite the recalcitrant (Spänhoff and Gessner 2004) and refractory nature of wood, several taxa ingest wood fragments (Pereira et al. 1982), and a few can digest (assimilate) wood (Monk 1976). As biofilms continue to develop over time, the wood is mechanically softened and its nutrient content and palatability increases (Anderson et al. 1978, Phillips and Kilambi 1994). Colonizing microorganisms and associated fine detritus also provide food for numerous aquatic invertebrates (Anderson 1982, Winterbourn 1982, Anderson et al. 1984, Tank et al. 2010). Lock et al. (1984) refers to biofilms accrued during conditioning as transducers of energy and matter that act as intermediates of polymer metabolism (e.g., cellulose) and are readily assimilated by stream invertebrates (Golladay and Sinsabaugh 1991, Hax and Golladay 1993, Eggert and Wallace 2007). Temporal modifications of wood structure and quality result in macroinvertebrate-wood interactions accompanied by shifts in community and biotic trait composition (Johnson et al. 2003).

Several investigators have examined the effects of wildfire on stream macroinvertebrates (Minshall et al. 1997, Minshall 2003, Vieira et al. 2004, Robinson et al. 2005, Malison and Baxter 2010, Oliver et al. 2012), but none addressed the role of fire-derived wood in stream function. Knowledge regarding interactions between macroinvertebrates and allochthonous inputs is based mainly on leaflitter studies (Wallace et al. 1997, Gessner et al. 1999, Graça 2001, Gulis et al. 2006, Casas et al. 2011), but leaf and wood decomposition differ greatly (e.g., Hax and Golladay 1993). Others have addressed the structural effects of wood, e.g., effects on flow patterns and retention (Entrekin et al. 2009, Testa et al. 2011) on macroinvertebrate communities in streams (Wallace et al. 1995, Hilderbrand et al. 1997, Lemly and Hilderbrand 2000, Warren and Kraft 2006). Last, some researchers have specifically examined the colonization of submerged wood by macroinvertebrates (Magoulick 1998, Collier and Halliday 2000, Collier and Smith 2003, Kaller and Kelso 2007, Lyon et al. 2009, Ballinger et al. 2010), but results have been inconsistent making generalizations difficult (Kaller and Kelso 2006).

We conducted a field experiment in which we manipulated the burn status (burned, unburned) and types of conditioning (water, soil, none) of small, uniform-sized pieces of freshly cut wood. Our objectives were to assess the effects of wood burn status, conditioning, and their interaction on macroinvertebrate community composition, taxon and functional diversity, and trait affinities (after Tachet et al. 2010). We hypothesized that: 1) colonization patterns would differ between burned and unburned wood because of physical, chemical, and nutritional degradation of burned wood; 2) colonization patterns would differ between conditioned (water, soil) and unconditioned wood because of the greater decay and prevalence of microorganisms on the surface of conditioned wood; and 3) colonization would differ between water- and soilconditioning. We expected conditioned wood to have the greatest taxonomic and functional diversity, and a higher prevalence of shredders (see Cummins and Klug 1979), and we expected more scrapers on wood that was conditioned in water (Hall et al. 2001).

\section{METHODS}

\section{Site description}

We worked in 3 unregulated $3^{\text {rd }}$-order streams (Strahler 1957) with 3 different upland forest types in each of 3 sepa- 
rate subbasins of the Tagus River in east-central Portugal: Fouvel, Alferreira, and Rio Frio. Geology at the streams was mainly characterized by siliceous rocks with low mineralization (INAG 2008). The area has gentle relief, and land cover is dominated by forests, shrublands, and agriculture. The local climate is Mediterranean with hot, dry summers and cool, wet winters. Mean annual precipitation is $512 \mathrm{~mm}$ (Fig. 1), and mean annual temperature is $15.8^{\circ} \mathrm{C}$ (range: $9^{\circ} \mathrm{C}$ in December-January to $23^{\circ} \mathrm{C}$ in JulyAugust).

The Fouvel subbasin (drainage area $=50 \mathrm{~km}^{2}$ ) is dominated by cork oak (Quercus suber) managed by an agroforestry system called montado (dehesa in Spain). The Alferreira subbasin $\left(59 \mathrm{~km}^{2}\right)$ has pure stands of eucalyptus (Eucalyptus globulus) planted for paper pulp production. The Rio Frio subbasin $\left(37 \mathrm{~km}^{2}\right)$ has pure stands of maritime pine (Pinus pinaster) grown for timber. The subbasins experienced extensive wildfires $(66,92$, and $71 \%$ burned area) between 2003 and 2007. After these fires, the amount of large wood in $3^{\text {rd }}$-order streams across the region was remarkably low: $2.8,2.9$, and 5.3 pieces $/ 100 \mathrm{~m}$ in subbasins dominated by cork oak, eucalyptus, and maritime pine, respectively. About $70 \%$ of this wood, including pieces of the dominant managed tree species (Vaz et al. 2011, 2013b), was burned.

The streams generally have neutral-basic waters and are intermittent with stretches that remain dry for several months in a seasonal sequence of floods and droughts. The natural discharge regime is primarily precipitationdominated with highest discharge occurring during autumn and winter. Discharge responds rapidly to precipitation events, which can result in major changes in flow over relatively short periods of time (Raven et al. 2009). Channel gradients at the study reaches were gentle $(\sim 1-2 \%)$. The Fouvel reach (lat $39^{\circ} 35^{\prime} 45.65^{\prime \prime} \mathrm{N}$, long $7^{\circ} 36^{\prime} 23.98^{\prime \prime} \mathrm{W}$, $151 \mathrm{~m}$ asl) had a treeless, sparsely vegetated riparian zone. This site was dominated by cobble and pebble substrates, interspersed with some boulders in the main channel and bedrock outcrops in one margin. The Alferreira (lat $39^{\circ} 28^{\prime}$ $3.81^{\prime \prime} \mathrm{N}$, long $7^{\circ} 51^{\prime} 17.46^{\prime \prime} \mathrm{W}, 127 \mathrm{~m}$ asl) and Rio Frio (lat $39^{\circ} 29^{\prime} 55.37^{\prime \prime} \mathrm{N}$, long $8^{\circ} 3^{\prime} 35.60^{\prime \prime} \mathrm{W}, 100 \mathrm{~m}$ asl) reaches had similar riparian vegetation, dominated by ash (Fraxinus angustifolia), alder (Alnus glutinosa), and black poplar (Populus nigra). The Rio Frio site also had silver wattle (Acacia dealbata) trees. The Alferreira reach was dominated by pebble and gravel substrates and Rio Frio mainly by gravel. Both reaches had some boulders in the main channel. During the study, maximum wetted widths were 7.22, 7.01, and $5.98 \mathrm{~m}$, at Fouvel, Alferreira, and Rio Frio reaches, respectively, with corresponding minimum water depths of 28,40 , and $30 \mathrm{~cm}$.

\section{Wood burning and preconditioning}

We used the dominant wood species in each subbasin as the species examined in the stream reach. We obtained freshly cut wood pieces with bark (length $=10 \mathrm{~cm}$, diameter $\approx 7.5 \mathrm{~cm}$, volume $\approx 442 \mathrm{~cm}^{3}$ ) of cork oak (mean mass $=$ $212 \mathrm{~g}$ ), maritime pine (344 g), and eucalyptus (398 g) (Fig. 2A). For each species, a replicate comprised 10 wood pieces $(1$ set). We used 54 sets of wood for the entire experiment: 18 sets each of cork oak, eucalyptus, and maritime pine.

We randomly selected 9 sets of each species (27 sets) and burned them at the Reaction to Fire Testing Laboratory, National Laboratory for Civil Engineering, in Lisbon, with a Single Burning Item EN 13823 (Fig. 2B). Pieces were burned for $20 \mathrm{~min}$ at $750^{\circ} \mathrm{C}$ (burner heat release $=$ $25 \mathrm{~kW} / \mathrm{h}$, gas flow to burner $=539 \mathrm{mg} / \mathrm{s}$ ). Mass lost measured immediately after burning was $26 \%$ for cork oak, $48 \%$ for maritime pine, and $54 \%$ for eucalyptus.

We randomly assigned 3 burned and 3 unburned sets of each species to 3 conditioning treatments: soil, water, and none. Soil-conditioned sets were left undisturbed on bare soil (slope $=5 \%$ ) with some low grasses (Fig. 2C, D) from 23 July 2010 to 15 April 2011 at the Institute of

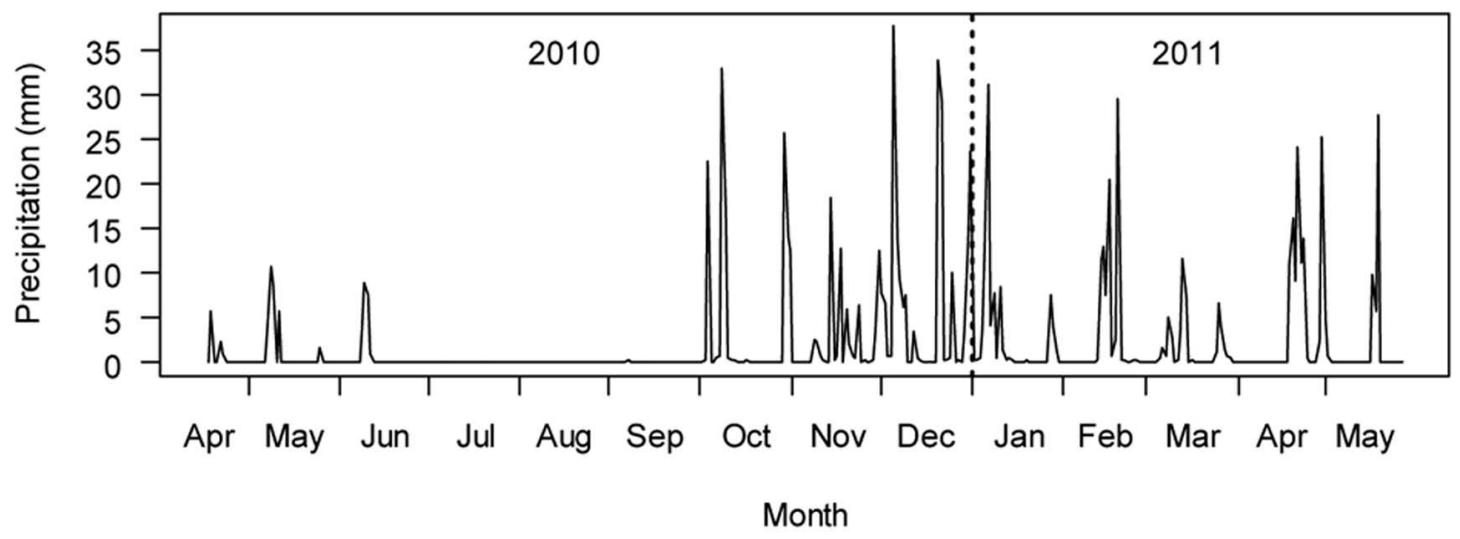

Figure 1. Local daily precipitation for the duration of the experiment (17 April 2010-26 May 2011). The rain gauge is 53, 29, and $12 \mathrm{~km}$ from Fouvel, Alferreira, and Rio Frio stream reaches, respectively. 

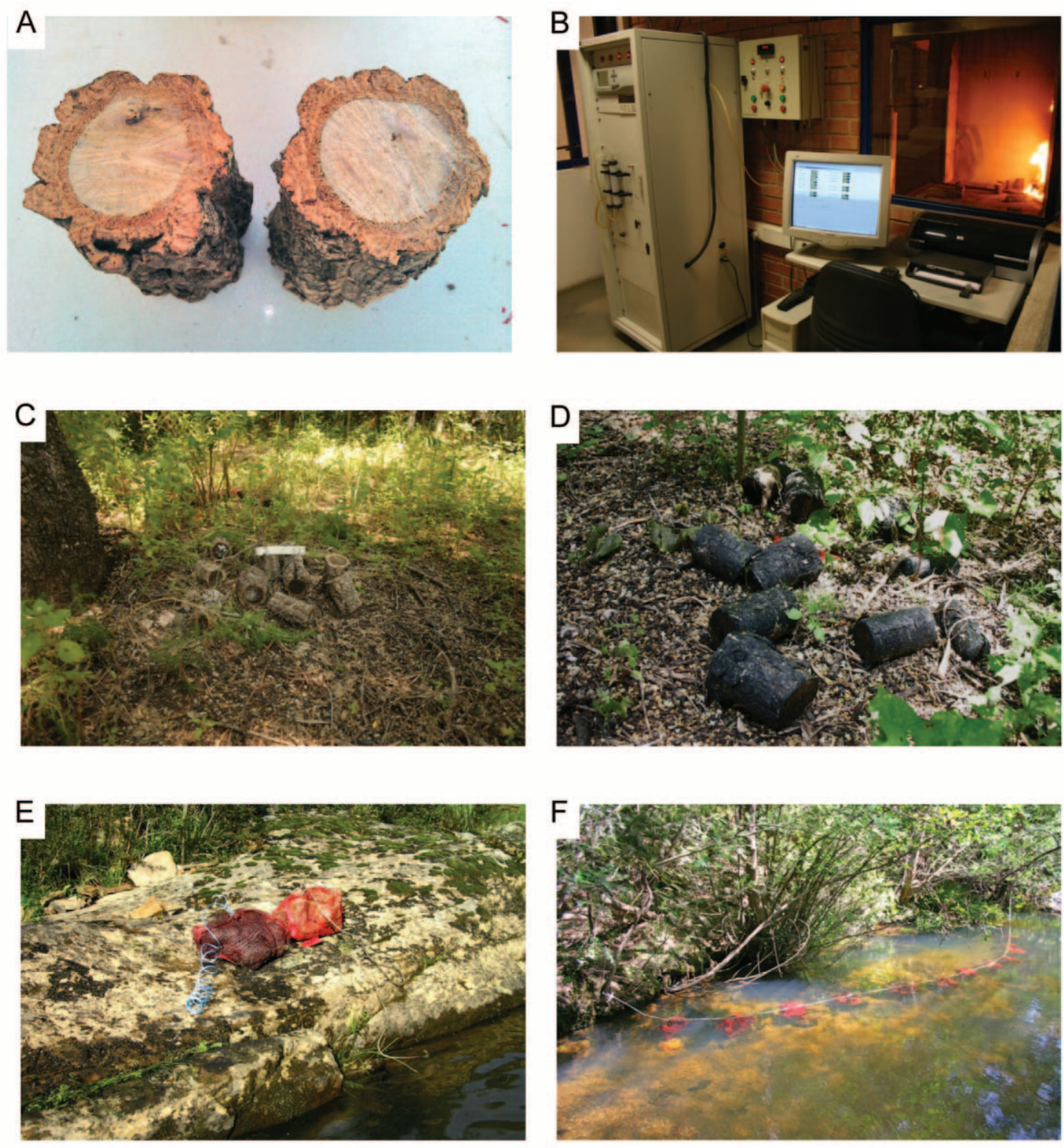

Figure 2. Photographs of the experimental setting showing freshly cut wood pieces (length $=10 \mathrm{~cm}$; diameter $\approx 7.5 \mathrm{~cm}$ ) from cork oak (A), burning process at the Reaction to Fire Testing Laboratory using a Single Burning Item (B), soil conditioning of unburned wood $(C)$ soil conditioning of burned wood $(D)$, mesh bags (mesh $=1.5 \times 1.5 \mathrm{~cm}$ ) with wood $(\mathrm{E})$, and mesh bags with wood secured in the stream with a nylon cable (F).

Agronomy campus (lat $38^{\circ} 42^{\prime} 42.00^{\prime \prime} \mathrm{N}$, long $9^{\circ} 11^{\prime} 20.13^{\prime \prime} \mathrm{W}$, $93 \mathrm{~m}$ asl). Soil was clay to clay loam with medium and wide cracks when dry (vertisol; IUSS 2006). Sets were arranged randomly in a $1 \times 1-\mathrm{m}$ regular grid (distance among sets $\leq 80 \mathrm{~cm}$ ). During conditioning, local mean daily temperature $5 \mathrm{~cm}$ above ground was $16.8^{\circ} \mathrm{C}\left(11.4-23.3^{\circ} \mathrm{C}\right)$, mean daily air humidity was $71.4 \%(56.8-81.8 \%)$, and mean daily solar insulation was $7.2 \mathrm{~h}(2.9-12.4 \mathrm{~h})$. Waterconditioned sets were submerged in plastic mesh bags (described below) in the stream reaches for 1 y between spring 2010 and spring 2011. Unconditioned sets were freshly cut in spring 2011 and underwent no further conditioning other than burning (described above).

\section{Field and laboratory procedures}

During the colonization step, we piled the pieces of each set irregularly in plastic mesh bags (mesh $=1.5 \times$ $1.5 \mathrm{~cm}$ ) (Fig. 2E). The bags prevented wood pieces from being swept away, but had large enough mesh to allow access of most invertebrates. On 17 April 2010, we placed the first sets in the water to be colonized for $\sim 1 \mathrm{y}$ (water 
conditioning). At each reach, we secured 3 burned and 3 unburned sets to a nylon cable in an alternating arrangement with bags spaced $\sim 80 \mathrm{~cm}$ apart (Fig. 2F). The bags were submerged in a line, and each bag was anchored to the stream bed with a boulder. On 29 April 2011, we added the sets that had undergone soil conditioning or no conditioning, mounted $<1.5 \mathrm{~m}$ from the first sets on nylon cables. Thus, at each $\sim 11$-m reach, another 12 bags were added and submerged, tethered in a random arrangement and spaced as above for a total of 18 sets/reach. Twelve sets assigned to water conditioning ( 6 at the cork oak reach, 3 each at the eucalyptus and maritime pine reaches) were destroyed and lost during winter floods.

On 26 May 2011, we collected the bags in buckets filled with stream water (1 bag/bucket). We separated all macroinvertebrates in each bag from the 10 wood pieces with a soft brush and a water spray bottle. Thus, all invertebrates on the 10 wood pieces combined constituted 1 sample. Visual assessment of the wood provided evidence that burning decreased the coating of epixylic biofilm and that decay of wood sets that had undergone soil conditioning or water conditioning was greater than decay of unconditioned wood. We filtered the water in each bucket through a $500-\mu \mathrm{m}$ mesh sieve to collect any remaining macroinvertebrates in the sample. We also used a kick-net $(500-\mu \mathrm{m}$ mesh net, aperture $=30 \mathrm{~cm})$ to collect a sample from the substrate at the previous location of each bag. We used this sample to characterize the reach in a different way to allow us to detect, for example, taxa that were not captured by the wood/mesh bags. Immediately after collection, we preserved macroinvertebrates, detached smaller pieces of wood, and loose bark with $70 \%$ ethanol in 1-L plastic flasks. We also characterized the location of each bag and recorded 3 stream microhabitat features: depth $(\mathrm{cm})$, bed substrate (gravel, pebbles, cobbles), and flow type (imperceptible, unbroken waves, broken waves, rippled). We defined bed substrates and flow types as in the River Habitat Survey Manual (EA 2003).

Upon returning to the laboratory, we cleaned and filtered (500- $\mu \mathrm{m}$ mesh sieve) samples and hand-picked all macroinvertebrates for identification with the aid of a microscope at $10 \times$ magnification. We identified macroinvertebrates to lowest-feasible taxonomic level (mostly family or genus) with available keys (e.g., Tachet et al. 2010, Oscoz et al. 2011) and counted them. We used absolute abundances/sample in all analyses.

\section{Macroinvertebrate traits}

We assigned ecological trait composition of each sample according to the traits database published by Tachet et al. (2010), which uses a fuzzy-coding procedure to describe the link between a taxon and categories within 21 traits (Usseglio-Polatera 1991, Chevenet et al. 1994, Usseglio-Polatera et al. 2000). In the database, each taxon is assigned a score that describes its affinity to each category of a given trait. Scores range from 0 (no affinity) to 3 or 5 (high affinity). The range of taxon-trait scores (0-3 or $0-5)$ depends on the available information in the literature and on the number of categories describing the trait. We used only the 5 traits that potentially influence wood colonization via food (food, feeding habits) or substrate affinities (maximal potential size, substrate preference, locomotion and substrate relation). We considered all categories describing each trait. After applying the scores to our data, we transformed the range of each taxon-trait category link by rescaling it between 0 and 1 .

\section{Functional diversity and taxon diversity}

We quantified functional diversity, i.e., the overall difference in terms of traits among taxa within a wood set with the Rao index of diversity (Botta-Dukát 2005, Lepš et al. 2006, De Bello et al. 2009, Lavorel et al. 2008). The Rao index represents the probability of picking 2 individuals in a community that differ in their ecological function. If the proportion of the $i^{\text {th }}$ taxon in a community is $p_{i}$ and the dissimilarity of taxon $i$ and $j$ is $d_{i j}$, the Rao index has the form

$$
\text { Functional diversity }=\sum_{i=1}^{t} \sum_{j=1}^{t} d_{i j} p_{i} p_{j}
$$

where $t$ is the number of taxa in the community and $d_{i j}$ varies from 0 ( 2 taxa having the same traits) to 1 (2 taxa having different traits). To convey taxon diversity, we used the Simpson index of diversity expressed as 1 minus Simpson index of dominance

$$
D=1-\sum_{i=1}^{t} p_{i}^{2} .
$$

\section{Data analysis}

Community by wood treatments We analyzed community composition in relation to explanatory variables by distance-based redundancy analysis (db-RDA; Legendre and Anderson 1999, McArdle and Anderson 2001), based on Bray-Curtis dissimilarities (Bray and Curtis 1957) on untransformed abundances, with the capscale algorithm in the $R$ package vegan (version 2.0-5; Dixon 2003, Oksanen et al. 2012). We used wood burn status (burned, unburned), conditioning (water, soil, none), the burn status $\times$ conditioning interaction, and habitat variables (water depth, streambed substrate, flow type) as predictors. We assessed final models with a forward variable selection procedure. We entered predictors one at a time, recorded their pseudo$F$ and significance values, and chose the most significant predictor. Then we entered all other independent variables and chose the next most significant ( $F$-test with anova com- 
mand in vegan; $p$-values generated by permutation using $p<0.05$ criteria). The procedure stopped when no significant term could be added. As a measure of overall dbRDA fit, we used the pseudo- $F$ ratio obtained by permutation tests (permutest command in vegan). Colonization conditions varied according to the site, so we first ran a $\mathrm{db}$-RDA model applied to the entire data set (sites combined) but with permutations stratified within sites, and then ran a separate model per site. The procedure can accommodate an unbalanced design, but $p$-values close to the 0.05 must be interpreted with special caution (Borcard et al. 2011).

We quantified the contributions of each taxon to the average Bray-Curtis dissimilarity between treatments (\% contribution) with a similarity percentages analysis (SIMPER; simper command in vegan; Clarke 1993). Taxon composition could differ among sites, so we ran SIMPER between treatments only within sites.

Taxa diversity, functional diversity, and trait affinity by wood treatments We $\operatorname{acrsin} \sqrt{ }(x)$-transformed taxon diversity, functional diversity, and trait affinity data to satisfy assumptions of normality before analysis. Groups of 3 conditioning treatments and 2 burn status treatments were nested within each site (one site/forest type: cork oak, eucalyptus, maritime pine), so we used a linear mixedeffect models (LMM) with site as a random factor (random intercept) for the analysis of response variables. We fitted a separate LMM to taxon diversity, functional diversity, and to each trait category with the above set of explanatory variables, and used the nlme package in $\mathrm{R}$ (version 3.1-104, R Project for Statistical Computing, Vienna, Austria; Pinheiro et al. 2012) to fit each model. In all cases, we started with a model with all 5 variables (burn status, conditioning, bed substrate, flow type, and depth) and the burn status $\times$ conditioning interaction in the fixed part of the model. We used backward elimination (Zuur et al. 2009) to remove each main term in turn, and then at each step, we applied the likelihood ratio test of nested models. We evaluated model adequacy by plotting residuals vs fitted values and explanatory variables.

\section{RESULTS}

We identified 79 macroinvertebrate taxa in the wood sets. Chironomidae was the most represented taxon (62\%), followed by Habrophlebia (13\%), Choroterpes (3\%), Ephemerella (3\%), Baetis (3\%), and Elmidae (3\%). Other taxa were less represented $(\leq 1 \%)$. Taxon composition differed among sites. For example, Choroterpes and Ephemerella were absent from eucalyptus and cork oak sites, respectively. Trichoptera and Plecoptera were rarely present in cork oak site samples, and Gastropoda did not occur at the eucalyptus site. Wood bags captured all taxa present in the kick-net samples at all sites (Appendix S1).

\section{Community by wood treatments}

Wood burn status was not selected for any of the $4 \mathrm{fi}$ nal db-RDA models (forward-selection, $\alpha \leq 0.05$; Table 1). Thus, wood burn status was not considered a significant predictor of community composition, whether we evaluated sites in combination or separately. In contrast, wood conditioning was a significant predictor of community composition in all cases, even though the water-conditioning treatment was absent at the cork oak site. The burn status $\times$ conditioning interaction also was not a significant predictor, indicating that the effect of conditioning probably was comparable for burned and unburned wood.

Community composition differed between conditioned (soil, water) and unconditioned wood sets when all sites were considered (Fig. 3A) and at each site separately (Fig. 3B-D). Community composition differed significantly between unconditioned and soil-conditioned wood at each site. However, differences between communities on waterand soil-conditioned wood depended on site (no differences when sites were combined, partial overlap at the eucalyptus site, different at the maritime pine site).

The taxon that contributed most to all significant dissimilarities between conditioning treatments within sites was Chironomidae, followed by Habrophlebia (except at the cork oak site) (Tables 2, 3, 4). Chironomidae was more abundant in unconditioned wood in all pairwise compar-

Table 1. Final distance-based redundancy analysis models (db-RDA) for macroinvertebrates on wood treated with no, soil, or water conditioning at all sites combined (analysis stratified by site) and separately for each site. At the cork oak site, data were available only for no and soil conditioning. Numbers in parentheses are pseudo- $F$ values, $p$-values were generated by 999 permutations and $p=0.01$ in the 4 models.

\begin{tabular}{lrrrr}
\hline \multicolumn{1}{c}{ Variable } & df & MS & $F$ & $p$ \\
\hline Sites combined (3.58) & & & & \\
$\quad$ Conditioning & 2 & 1.10 & 5.89 & 0.01 \\
$\quad$ Streambed substrate & 3 & 0.67 & 2.40 & 0.01 \\
$\quad$ Water depth & 1 & 0.23 & 2.49 & 0.01 \\
$\quad$ Residuals & 33 & 3.09 & & \\
Cork oak site (5.71) & & & & \\
$\quad$ Water depth & 1 & 0.47 & 7.82 & 0.01 \\
$\quad$ Conditioning & 1 & 0.21 & 3.60 & 0.02 \\
$\quad$ Residuals & 9 & 0.53 & & \\
Eucalyptus site (5.20) & & & & \\
$\quad$ Conditioning & 2 & 1.03 & 6.36 & 0.01 \\
$\quad$ Water depth & 1 & 0.23 & 2.88 & 0.02 \\
$\quad$ Residuals & 11 & 0.89 & & \\
Maritime pine site (4.21) & & & & \\
$\quad$ Conditioning & 2 & 0.54 & 4.21 & 0.01 \\
$\quad$ Residuals & 12 & 0.77 & & \\
\hline
\end{tabular}



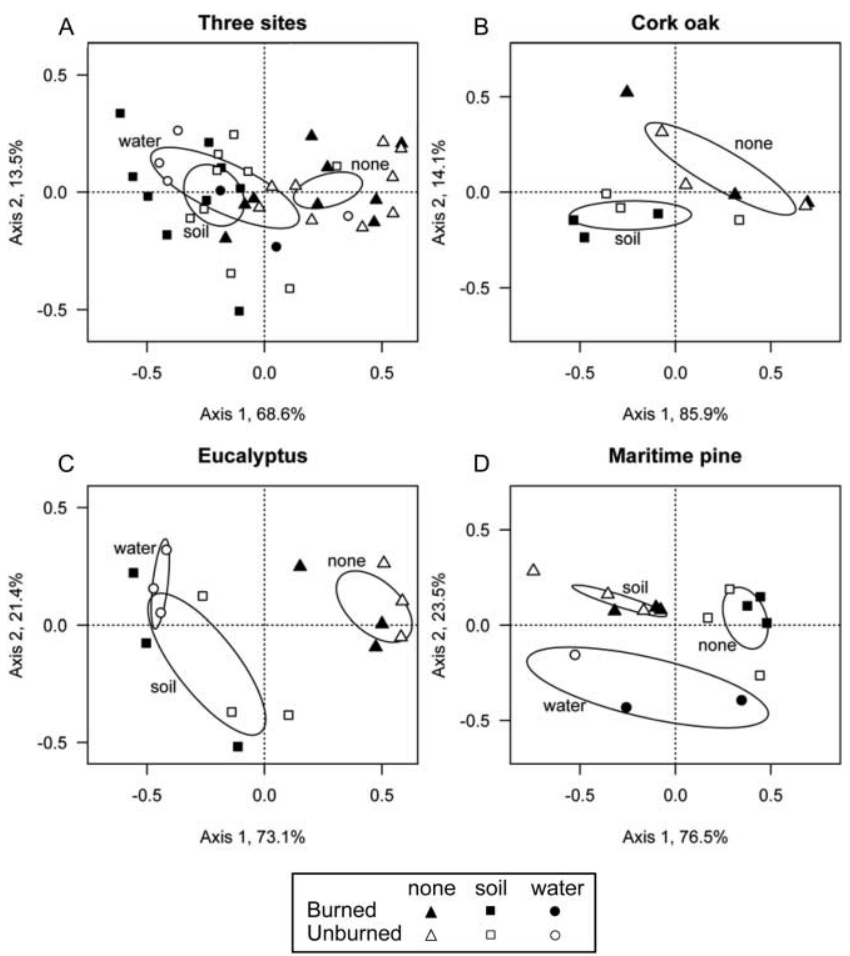

Figure 3. Distance-based redundancy analysis (db-RDA) ordination plots for macroinvertebrates on burned and unburned wood at all sites combined (A), and cork oak (B), eucalyptus (C), and maritime pine (D) sites. Percentages next to axis titles are $\%$ variance explained by axis. Ellipses indicate where $95 \%$ of sampling units with the same conditioning (none, soil, water) are expected to occur. Water-conditioning data were absent for the cork oak site and sample size was reduced at eucalyptus and maritime pine sites.

isons involving this wood treatment. Other taxa that contributed $>5 \%$ of the dissimilarity between at least 1 pair of conditioning treatments within sites were Choroterpes, Baetis, Ephemerella, Elmidae, Thaumaleidae, Psychodidae, and Psychomyiidae (Appendix S2).

\section{Taxon diversity, functional diversity, and trait affinity by wood treatments}

Wood burn status was not a significant predictor of taxon or functional diversity, nor, in general, of trait affinity (Table 5). Wood conditioning was a significant predictor of taxon diversity, functional diversity, and of trait affinity for 23 categories among the traits assessed. The burn status $\times$ preconditioning interaction was always dropped during the model-selection processes, indicating that the effect of conditioning was independent of burn status. Fitted values for taxon diversity and functional diversity were lower for unconditioned wood than for soil- or water-conditioned wood and did not differ between soil- and water-conditioned $\operatorname{wood}($ Fig. 4).

Pairwise comparisons of fitted trait affinity between wood conditioning treatments generally revealed that un-

conditioned wood differed significantly from the other 2 treatments (Fig. 5). In 20 of the 23 categories, the confidence intervals of mean trait affinity on unconditioned wood did not overlap with the trait affinity on wood with soil or water conditioning (Fig. 5), i.e., trait affinities differed significantly. Macroinvertebrates colonizing wood were characterized as follows based on food or substrate affinities.

Food Fewer shredders and more filter-feeders, predators, and parasites occurred on unconditioned than on conditioned wood. Macroinvertebrates tended to feed less on living microphytes, and more on microorganisms, detritus $<1 \mathrm{~mm}$, dead animals $\geq 1 \mathrm{~mm}$, living microinvertebrates, and living macroinvertebrates on unconditioned than on conditioned wood.

Substrate affinities Only 2 of the 7 maximal potential size categories of macroinvertebrates (1-2 and 2-4 cm; Tachet et al. 2010) tended to be more prevalent on unconditioned than on conditioned wood. Unconditioned wood was colonized by macroinvertebrates with less affinity to twigs/roots as preferred substrate and more affinity to mud, microphytes, sand, or flags/boulders/cobbles/pebbles. Macroinvertebrates colonizing water-conditioned wood had higher affinity for permanent or temporary attachment to substrates than for other locomotion/substrate categories, whereas unconditioned wood tended to have macroinvertebrates with more interstitial or burrower habits than

Table 2. Output of similarity percentages analysis at the cork oak site showing taxa responsible for $90 \%$ of the overall average dissimilarity between the macroinvertebrate communities on wood with no or soil conditioning. Bold highlights the conditioning treatment in which the taxon was more abundant. Ctr\% $=\%$ contribution to the overall dissimilarity between conditioning treatments. No data were available for water conditioning at the cork oak site.

\begin{tabular}{lrrrr}
\hline \multicolumn{1}{c}{ Taxon } & \multicolumn{2}{c}{$\begin{array}{c}\text { Mean } \\
\text { abundance }\end{array}$} & $\begin{array}{c}\text { Overall } \\
\text { dissimilarity (\%) }\end{array}$ & Ctr\% \\
\hline Comparison & Soil & None & 47.6 & \\
Chironomidae & 117.5 & $\underline{\mathbf{2 5 6 . 5}}$ & & 56.3 \\
Elmidae & $\underline{\mathbf{2 1 . 7}}$ & 10.7 & & 7.2 \\
Choroterpes & $\underline{\mathbf{2 7 . 2}}$ & 20.0 & 5.9 \\
Thaumaleidae & 0.5 & $\underline{\mathbf{1 2 . 2}}$ & 5.2 \\
Psychodidae & 0.5 & $\underline{\mathbf{1 2 . 0}}$ & 5.2 \\
Naididae & 0.8 & $\underline{\mathbf{5 . 2}}$ & & 2.1 \\
Cloeon & 0.5 & $\underline{\mathbf{4 . 3}}$ & & 1.8 \\
Centroptilum & $\underline{\mathbf{4 . 8}}$ & $\mathbf{3 . 7}$ & 1.5 \\
Dixidae & 1.3 & $\underline{\mathbf{2 . 7}}$ & & 1.4 \\
Procloeon & 1.5 & $\underline{\mathbf{3 . 7}}$ & & 1.3 \\
Dytiscidae & 2.3 & $\underline{\mathbf{3 . 5}}$ & & 1.1 \\
\hline
\end{tabular}


Table 3. Output of similarity percentages analysis at the eucalyptus site showing taxa responsible for $90 \%$ of the overall average dissimilarity between the macroinvertebrate communities on wood with no, water, or soil conditioning. Bold highlights the conditioning treatment in which the taxon was more abundant. $\mathrm{Ctr} \%=\%$ contribution to the overall dissimilarity between conditioning treatments. No differences were detected between communities on wood with soil and water conditioning.

\begin{tabular}{lrrrr}
\hline \multicolumn{1}{c}{ Taxon } & \multicolumn{2}{c}{$\begin{array}{c}\text { Mean } \\
\text { abundance }\end{array}$} & $\begin{array}{c}\text { Overall } \\
\text { dissimilarity (\%) }\end{array}$ & Ctr\% \\
\hline Comparison & Water & None & 61.2 & \\
Chironomidae & 85.3 & $\underline{\mathbf{3 8 6 . 5}}$ & & 68.4 \\
Habrophlebia & $\underline{\mathbf{6 1 . 0}}$ & 54.0 & & 7.6 \\
Ephemerella & 0.3 & $\underline{\mathbf{3 3 . 2}}$ & & 7.3 \\
Psychomyiidae & $\underline{\mathbf{2 1 . 3}}$ & 0.5 & & 5.0 \\
Comparison & Soil & None & 60.7 & \\
Chironomidae & 88.8 & $\underline{\mathbf{3 8 6 . 5}}$ & & 71.3 \\
Habrophlebia & 29.0 & $\underline{\mathbf{5 4 . 0}}$ & & 9.0 \\
Ephemerella & 21.3 & $\underline{\mathbf{3 3 . 2}}$ & & 6.2 \\
Baetis & 7.0 & $\underline{\mathbf{1 7 . 3}}$ & & 3.3 \\
\hline
\end{tabular}

preconditioned wood. Macroinvertebrates having higher crawler affinity were most prevalent on soil-conditioned wood followed by unconditioned and water-conditioned wood. Full water swimmers were more prevalent on unconditioned wood than on soil-conditioned wood, whereas macroinvertebrates on water-conditioned wood had an intermediate affinity for this trait category.

\section{DISCUSSION}

\section{Burned stream wood and macroinvertebrates}

The data did not support our $1^{\text {st }}$ hypothesis that patterns of stream macroinvertebrate colonization would differ in response to wood burning. Central to our expectation was the nutritional depletion of burned wood, in line with the observed decreased coat of biofilm. We were not able to measure biofilm growth (e.g., chlorophyll $a$ ), but the nutritional depletion of other burned allochthonous inputs is recognized in the literature. For example, Mihuc and Minshall (1995) found that only 1 macroinvertebrate taxon was able to grow when fed burned organic matter. In addition, Gama et al. (2007) reported a reduction in nutritional quality of fire-exposed leaves relative to normal eucalyptus leaves in a central Portugal stream. However, the diversity and macroinvertebrate abundance were similar between treatments (Gama et al. 2007). Our study followed the same trend, in which alteration of stream wood quality by fire did not appear to be a determinant of macroinvertebrate colonization. The degree of xylophagy differs among regions (Benke and Wallace 2003), and our results suggest colonization by predominantly nonxylophages
Table 4. Output of similarity percentages analysis at the maritime pine site showing taxa responsible for $90 \%$ of the overall average dissimilarity between the macroinvertebrate communities on wood with no, water, or soil conditioning. Bold highlights the conditioning treatment in which the taxon was more abundant. Ctr\% $=\%$ contribution to the overall dissimilarity between conditioning treatments.

\begin{tabular}{|c|c|c|c|c|}
\hline \multirow{2}{*}{$\frac{\text { Taxon }}{\text { Comparison }}$} & \multicolumn{2}{|c|}{$\begin{array}{c}\text { Mean } \\
\text { abundance }\end{array}$} & \multirow{2}{*}{$\begin{array}{c}\begin{array}{c}\text { Overall } \\
\text { dissimilarity (\%) }\end{array} \\
38.2\end{array}$} & \multirow[t]{2}{*}{ Ctro } \\
\hline & Water & None & & \\
\hline Chironomidae & 95.0 & $\underline{119.0}$ & & 37.0 \\
\hline Habrophlebia & $\underline{41.3}$ & 38.8 & & 11.9 \\
\hline Baetis & $\underline{22.0}$ & 5.7 & & 10.8 \\
\hline Simuliidae & $\underline{6.7}$ & 0.7 & & 4.0 \\
\hline Lumbricidae & $\underline{5.3}$ & 0.0 & & 4.1 \\
\hline Physa & 0.0 & $\underline{5.0}$ & & 3.3 \\
\hline Choroterpes & 0.0 & $\underline{4.5}$ & & 3.1 \\
\hline Polycentropodidae & $\underline{5.3}$ & 3.5 & & 2.8 \\
\hline Elmidae & 0.3 & $\underline{4.5}$ & & 2.8 \\
\hline Hydropsychidae & $\underline{3.0}$ & 0.0 & & 1.8 \\
\hline Beraeidae & 0.0 & $\underline{2.5}$ & & 1.8 \\
\hline Dixidae & 1.0 & $\underline{2.0}$ & & 1.6 \\
\hline Rhyacophila & $\underline{2.3}$ & 0.0 & & 1.4 \\
\hline Leuctridae & $\underline{2.0}$ & 0.0 & & 1.3 \\
\hline Ephemerella & $\underline{2.3}$ & 1.3 & & 1.3 \\
\hline Comparison & Soil & None & 45.2 & \\
\hline Chironomidae & 44.5 & $\underline{119.0}$ & & 49.6 \\
\hline Habrophlebia & $\underline{55.5}$ & 38.8 & & 18.5 \\
\hline Choroterpes & $\underline{10.5}$ & 4.5 & & 5.2 \\
\hline Baetis & 5.5 & $\underline{5.7}$ & & 3.6 \\
\hline Elmidae & $\underline{7.7}$ & 4.5 & & 3.0 \\
\hline Physa & 1.7 & $\underline{5.0}$ & & 2.8 \\
\hline Polycentropodidae & $\underline{5.0}$ & 3.5 & & 1.8 \\
\hline Beraeidae & 0.7 & $\underline{2.5}$ & & 1.5 \\
\hline Dixidae & 0.5 & $\underline{2.0}$ & & 1.5 \\
\hline Centroptilum & $\underline{1.3}$ & 0.3 & & 1.2 \\
\hline Ephemerella & $\underline{2.2}$ & 1.3 & & 1.2 \\
\hline Comparison & Water & Soil & 46.5 & \\
\hline Chironomidae & $\underline{95.0}$ & 44.5 & & 33.7 \\
\hline Habrophlebia & 41.3 & $\underline{55.5}$ & & 12.7 \\
\hline Baetis & $\underline{22.0}$ & 5.5 & & 10.3 \\
\hline Choroterpes & 0.0 & $\underline{10.5}$ & & 6.3 \\
\hline Elmidae & 0.3 & $\underline{7.7}$ & & 4.6 \\
\hline Lumbricidae & $\underline{5.3}$ & 0.0 & & 3.9 \\
\hline Simuliidae & $\underline{6.7}$ & 0.3 & & 3.8 \\
\hline Polycentropodidae & $\underline{5.3}$ & 5.0 & & 2.7 \\
\hline Hydropsychidae & $\underline{3.0}$ & 0.0 & & 1.8 \\
\hline Rhyacophila & $\underline{2.3}$ & 0.0 & & 1.3 \\
\hline Ephemerella & $\underline{2.3}$ & 2.2 & & 1.3 \\
\hline Leuctridae & $\underline{2.0}$ & 0.0 & & 1.2 \\
\hline Dytiscidae & 0.0 & $\underline{1.7}$ & & 1.1 \\
\hline Centroptilum & 0.0 & $\underline{1.3}$ & & 1.0 \\
\hline Lumbriculidae & 1.0 & $\underline{1.2}$ & & 1.1 \\
\hline Physa & 0.0 & $\underline{1.7}$ & & 0.9 \\
\hline Hydraena & $\underline{1.7}$ & 0.0 & & 1.0 \\
\hline Philopotamidae & $\underline{1.3}$ & 0.0 & & 0.8 \\
\hline
\end{tabular}


Table 5. Significance levels for fixed terms in optimal linear mixed-effects models predicting taxon or functional diversity and trait affinity by wood burn status (burn) and conditioning (cond) type. Only those trait categories where the effect of wood conditioning was significant are shown. Sub $=$ streambed substrate. Blank cells were terms dropped during the model selection process. $* * * * 0.001,{ }^{* * *}=<0.01, *=<0.05$.

\begin{tabular}{|c|c|c|c|c|c|c|c|c|}
\hline \multirow{2}{*}{ Variable } & \multirow[b]{2}{*}{ Response } & \multicolumn{6}{|c|}{ Model predictors } & \multirow[b]{2}{*}{$R^{2}$} \\
\hline & & Cond & Burn & Burn $\times$ Cond & Sub & Flow & Depth & \\
\hline \multirow[t]{2}{*}{ Diversity } & Taxon diversity & $* * *$ & & & & & $* *$ & 0.44 \\
\hline & Functional diversity & $* * \%$ & & & $*$ & & & 0.41 \\
\hline Trait & Trait category & & & & & & & \\
\hline \multirow[t]{2}{*}{ Maximal potential size } & $2-4 \mathrm{~cm}$ & $* * *$ & $*$ & & & & & 0.45 \\
\hline & $1-2 \mathrm{~cm}$ & $* * *$ & & & & & & 0.41 \\
\hline \multirow[t]{5}{*}{ Substrate (preferendum) } & Mud & $* * *$ & & & & & & 0.50 \\
\hline & Twigs/roots & * & & & & & & 0.17 \\
\hline & Microphytes & $* * *$ & & & & & & 0.44 \\
\hline & Sand & $* * *$ & & & $* *$ & & & 0.61 \\
\hline & Flags/boulders/cobbles/pebbles & $\%$ & & & $*$ & & & 0.46 \\
\hline \multirow[t]{6}{*}{ Locomotion and substrate relation } & Permanently attached & $\% * \%$ & & & & & $* \%$ & 0.43 \\
\hline & Temporarily attached & $\% *$ & & & & & $*$ & 0.41 \\
\hline & Interstitial & $* \%$ & & & $* *$ & & & 0.51 \\
\hline & Burrower & $* * *$ & & & $* * *$ & & & 0.62 \\
\hline & Crawler & $* * \%$ & & & & & $*$ & 0.51 \\
\hline & Full water swimmer & $\%$ & & & & $\%$ & $*$ & 0.13 \\
\hline \multirow[t]{6}{*}{ Food } & Living macroinvertebrates & $* * *$ & & & & & & 0.34 \\
\hline & Living microinvertebrates & $* * *$ & & & $* *$ & & & 0.54 \\
\hline & Dead animal $\geq 1 \mathrm{~mm}$ & $* *$ & & & & & $\%$ & 0.35 \\
\hline & Living microphytes & $*$ & & & & & & 0.13 \\
\hline & Detritus $<1 \mathrm{~mm}$ & $*$ & & & $* *$ & & & 0.53 \\
\hline & Microorganisms & $\% *$ & & & $*$ & & & 0.36 \\
\hline \multirow[t]{4}{*}{ Feeding habits } & Parasite & $* * *$ & $*$ & & $* *$ & & & 0.61 \\
\hline & Predator & $* * *$ & & & $*$ & & & 0.49 \\
\hline & Filter-feeder & $* * \%$ & & & $*$ & & & 0.47 \\
\hline & Shredder & $*$ & & & $*$ & & & 0.40 \\
\hline
\end{tabular}

(sensu Hoffmann and Hering 2000). Like Gama et al. (2007), we suggest that invertebrates colonizing wood may use it more as substratum than as food. Our results showed that fire-induced changes in quality of allochthonous inputs per se may not alter the structure of macroinvertebrate communities. In his review regarding responses of macroinvertebrates to fire, Minshall (2003) noted that most results support the conclusion that fire is not detrimental to sustained maintenance of diverse and productive aquatic ecosystems. Our results align well with Minshall's statement that "there is no fire crisis" (Minshall 2003, p. 159).

\section{Taxon responses}

Our $2^{\text {nd }}$ hypothesis that preconditioning would lead to changes in macroinvertebrate community assembly was clearly supported, independent of wood burn status. The number of individuals was consistently higher and was composed of a higher proportion of chironomids on unconditioned than on conditioned wood (Appendix S1). Chironomids are frequently among the first colonizers of submerged wood (McLachlan 1970, Nilsen and Larimore 1973, Spänhoff et al. 2000). As expected, greater taxon and functional diversity was found on conditioned than on unconditioned wood. This difference might be the result of the more advanced state of decay, higher prevalence of microorganisms, or greater microhabitat diversity on the surface of conditioned than of unconditioned wood. We suggest that the decrease in the relative dominance of chironomids (Cummins and Klug 1979) and coexistence of more taxa (O'Connor 1991) might have been a consequence of greater resource availability on conditioned than on unconditioned wood. Collier and Halliday (2000) documented dominant species with varying preferences for 


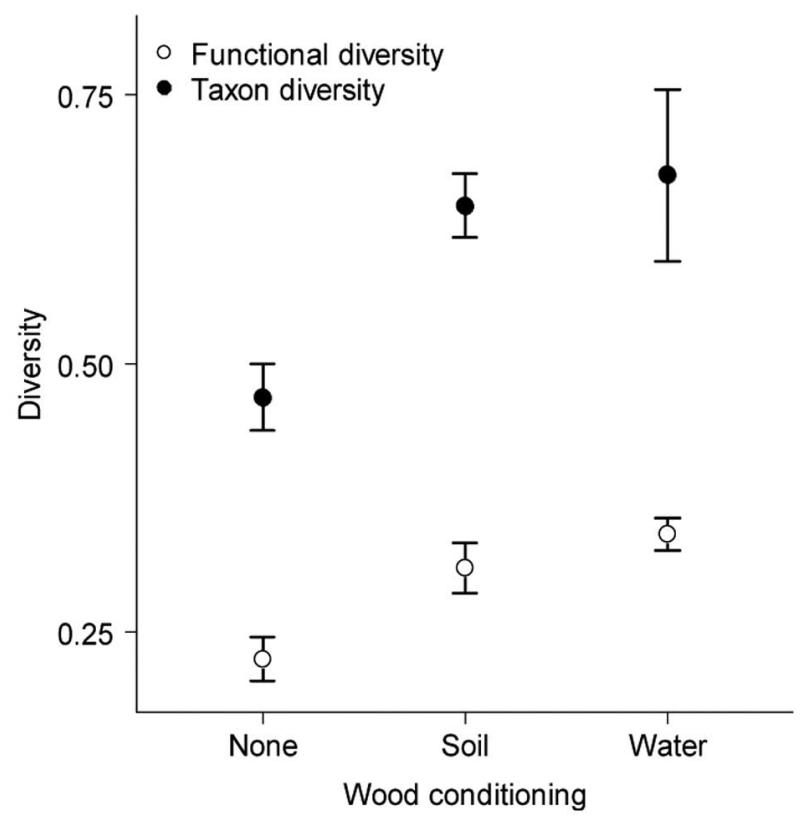

Figure 4. Mean $( \pm 95 \%$ CI $)$ fitted values for the optimal mixed-effects models predicting taxon or functional diversity by type of wood conditioning.

wood at different stages of decay, and their findings suggested invertebrate community succession with increasing wood decay. In our study, chironomids were the major pioneer taxon on unconditioned wood, whereas more diverse but less dense communities were attained on waterand soil-conditioned wood.

Wood that entered the stream after some time on the forest floor was colonized by macroinvertebrates differently than wood that entered the channel directly. This terrestrial legacy had already been hypothesized (see Anderson et al. 1984), but it has never been tested explicitly in a multiple-factor experimental setting. Some authors have addressed the effect of the stage of decay of stream wood on macroinvertebrates but the decay process (e.g., terrestrial, aquatic, or both) has rarely been controlled. In general, authors of observational studies and singlefactor experiments have reported relationships between wood decay and diversity, richness, or density (Benke and Wallace 2003). For instance, invertebrate richness may increase with decay (Braccia and Batzer 2001, Ballinger et al. 2010), and density may vary (Collier and Halliday 2000) or be unrelated to decay (Braccia and Batzer 2001). Based on some of these studies and on their own findings, Kaller and Kelso (2006) stressed the difficulty of making generalizations about the effect of decay on macroinvertebrates. We think that part of the difficulty arises from limited tracking of crucial features in the decay of sampled wood, such as decay time, age, size, species, and waterlogging period. We controlled these variables and were able to measure the effects of wood conditioning on the structure of stream invertebrate communities.
The invertebrate community on wood after $1 \mathrm{y}$ of submergence (water-conditioning) differed from the community on unconditioned wood colonized over 1 mo. A time series analysis is beyond the scope of our study, but we suggest that this result indicates a possible shift in community composition over the $1-y$ period. For instance, the community on water-conditioned wood probably had more chironomids a month after initial submergence. On the other hand, macroinvertebrate communities did not differ markedly between water- and soil-conditioned wood even though the duration of in-stream colonization varied between the 2 conditioning treatments $(1 \mathrm{y}$ vs $1 \mathrm{mo})$. Communities on water- and soil-conditioned wood had similar diversities (taxon and functional) at the eucalyptus and maritime pine sites, and community composition differed significantly only at the maritime pine site. If invertebrate communities do undergo succession during water-conditioning (Collier and Halliday 2000), we suggest that the first stage of that succession can be influenced by soil conditioning, although the progress of succession would be site-specific. Our ability to draw inferences regarding water conditioning would have been stronger had we been able to include data from the cork oak site. More work is necessary to shed light on these possibilities.

\section{Trait responses}

We quantified trait affinities to examine the influence of wood treatments on macroinvertebrate communities. Taxonomy-based metrics are often poor tools for identifying the mechanisms underlying patterns, whereas modeling trait responses allowed us to better understand how the functional role of communities was constrained (Wooster et al. 2012). Shredders usually select the most conditioned material (Cummins and Klug 1979), and as expected, taxa with higher shredding affinity were associated with conditioned wood. However, our prediction of higher prevalence of scrapers on water- than on soil-conditioned wood was not supported. We based our prediction on the expectation that periphyton growth would be greater on water- than on soil-conditioned wood (Oliver et al. 2012), but the conditioning period might have been too short for us to detect a response (Golladay and Webster 1988, Hall et al. 2001).

Less specialized feeders with a large breadth of food requirements (Oliver et al. 2012) prevailed on unconditioned wood. For example, the higher proportion of predators on unconditioned than on conditioned wood might be explained by the greater abundance of macroinvertebrates (potential prey) on unconditioned wood (Malison and Baxter 2010). Also, filter-feeders do not depend on biofilm accrual because their food is produced elsewhere in the system and is delivered by drift (Benke and Wallace 2003). Thick biofilms may inhibit filter-feeders from making firm attachments to the underlying substrate. Con- 


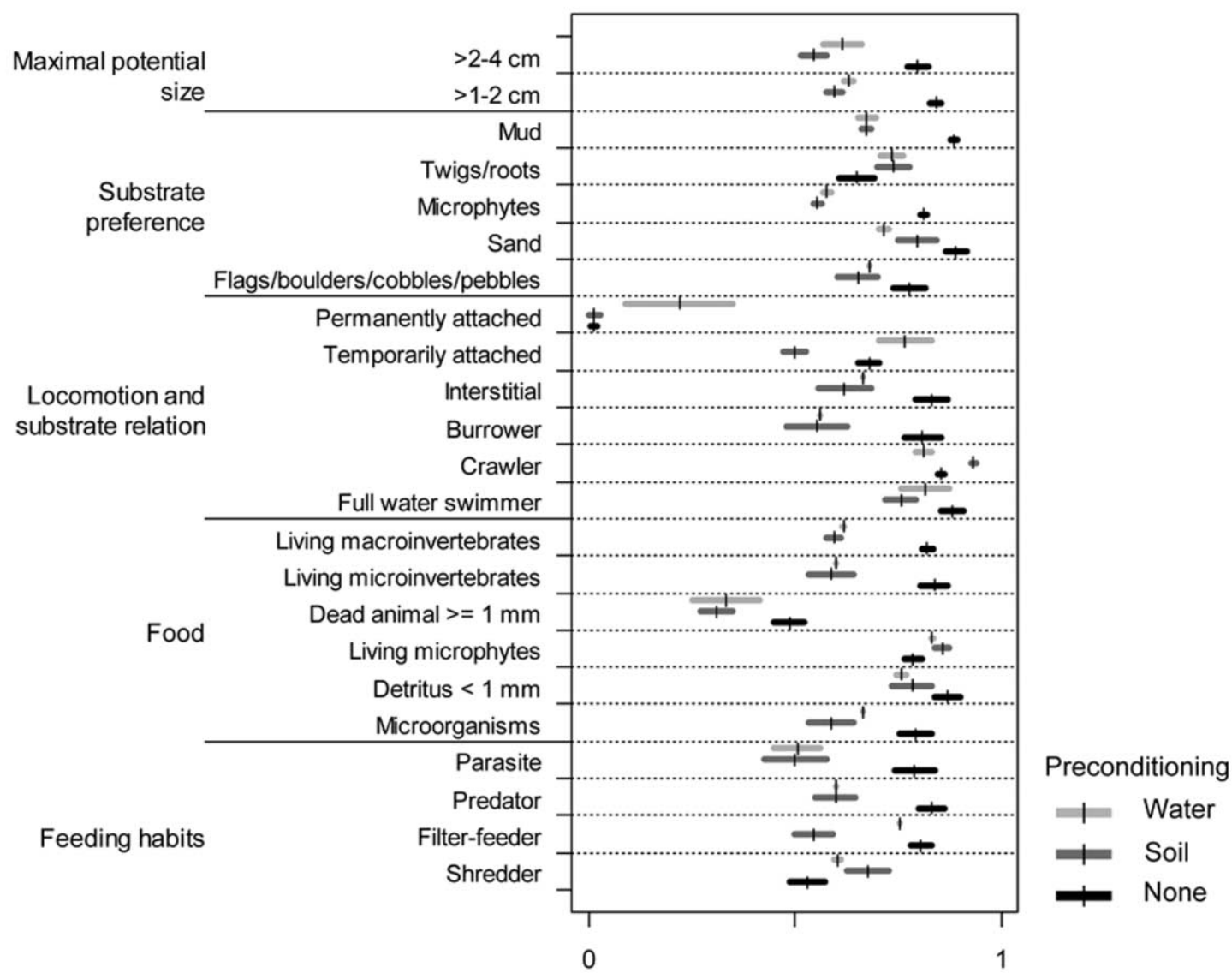

Trait affinity

Figure 5. Mean fitted values (vertical ticks) and $\pm 95 \%$ confidence intervals (horizontal bars) for the optimal mixed-models predicting trait affinity by wood conditioning treatment. One model was run for each category within traits. Only those trait categories where the effect of wood conditioning was significant are shown.

versely, taxa with shredder and living microphytes affinities were correlated within wood sets (mean $r_{s}>0.8$ ) and were more common on conditioned than unconditioned wood, a result consistent with previous work on the relationship between microphyte abundance and the number of shredders on stream wood (Spänhoff et al. 2006). Macroinvertebrates preferring wood substrates (twigs/roots) prevailed on the conditioned wood, whereas taxa preferring some other substrates prevailed on the unconditioned wood. This result lends support to the notion that use of unconditioned wood was opportunistic. Overall, food and substrate affinities were similar between water- and soilconditioned wood, except for 'locomotion and substrate relation'. Most individuals did not use the wood for permanent attachment, although the affinity for attachment was higher on water-conditioned wood than on soilconditioned or unconditioned wood. Interstitial, burrower, and full water swimmer affinities were high on unconditioned wood, a pattern that further suggests opportunistic use of this wood (e.g., refuge or perching habitat).
In our study, wood conditioning, whether in the stream or on the forest floor, was important to macroinvertebrate taxa and trait responses. In contrast, Pitt and Batzer (2011) found that conditioning had minimal influence on how wood was used by macroinvertebrates in streams in the southeastern USA. Kaller and Kelso (2006) suggested that stream invertebrates readily used all incoming wood regardless of its condition, and they invoked opportunistic colonization as the primary mechanism explaining similar assemblages on wood with various conditioning. In disentangling this contradiction between our results and those reported by others, we first note that our systems differ markedly from those where most other related work has been conducted. Some studies were conducted in sand- or silt-dominated streams and in the absence of stable rocky materials, so wood may have been the only stable habitat available. Such circumstances would decrease the importance of conditioning. However, in all of our study streams, macroinvertebrates had other stable substrates that were readily available, so reliance on wood per se may have been 
less pronounced, and preconditioning would acquire greater importance as biofilms become a more important direct food source.

\section{Concluding remarks}

We worked in 3 common southern European fireprone forest types where tree mortality associated with fire contributes riparian and upland wood to stream ecosystems (Vaz et al. 2011, 2013a, b) every year. We responded to a need and to an opportunity and conducted a first study of the effect of fire-derived wood on the structure of stream macroinvertebrate communities. In contrast to our expectations, taxonomic or functional patterns of stream macroinvertebrate colonization did not differ substantially between burned and unburned wood, even after a year of incubation in the stream or on the forest floor. This finding is an important contribution to our understanding of how wildfire structures aquatic communities and it can be used to guide postfire stream and riparian management operations that take ecosystem function into account. In conclusion, when fire affects riparian trees, the path by which fallen wood enters the stream has a greater influence on colonization by epidendric macroinvertebrates than whether the wood has been burned. Ultimately, biotic rather than abiotic conditioning influences invertebrate communities on wood following fire, and this fact has implications for the response of the entire stream food web.

\section{ACKNOWLEDGEMENTS}

We thank Júlio Sampaio and C. Pina Santos (Reaction to Fire Testing Laboratory-Portuguese National Laboratory for Civil Engineering) for help on the controlled wood burning. We also appreciate the advice of Paulo Fernandes (Centre for Research and Technology of Agro-Environmental and Biological Sciences, UTAD) on the burning process. Nuno Cortez (Section of Soil Science, DCA-ISA) helped us with soil conditioning. We are grateful to P. Usseglio-Polatera for giving us access to the latest version of the database of traits. We also thank A. SchmidtKloiber for giving us full access to the freshwaterecology.info database. We are especially grateful to the students who helped in the processing of samples in the laboratory, in particular to Nuno Bem and João Gameiro. Financial support by the Portuguese Foundation for Science and Technology (SFRH/BD/45490/ 2008 and PEst-OE/AGR/UI0520/2011) to PV is gratefully acknowledged.

\section{LITERATURE CITED}

Anderson, N. H. 1982. A survey of aquatic insects associated with wood debris in New Zealand streams. Mauri Ora 10: 21-33.

Anderson, N. H., J. R. Sedell, L. M. Roberts, and F. J. Triska. 1978. The role of aquatic invertebrates in processing of wood debris in coniferous forest streams. American Midland Naturalist 100:64-82.
Anderson, N. H., R. J. Steedman, and T. Dudley. 1984. Patterns of exploitation by stream invertebrates of wood debris (xylophagy). Verhandlungen der Internationalen Vereinigung für theoretische und angewandte Limnologie 22:1847-1852.

Arseneault, D., E. Boucher, and E. Bouchon. 2007. Asynchronous forest-stream coupling in a fire-prone boreal landscape: insights from woody debris. Journal of Ecology 95:789-801.

Ballinger, A., R. M. Nally, and P. S. Lake. 2010. Decay state and inundation history control assemblage structure of log-dwelling invertebrates in floodplain forests. River Research and Applications 26:207-219.

Benke, A. C., and J. B. Wallace. 2003. Influence of wood on invertebrate communities in streams and rivers. Pages 149177 in S. V. Gregory, K. L. Boyer, and A. M. Gurnell (editors). The ecology and management of wood in world rivers. American Fisheries Society, Bethesda, Maryland.

Borcard, D., F. Gillet, and P. Legendre. 2011. Numerical ecology with R. Springer, New York, USA.

Botta-Dukát, Z. 2005. Rao's quadratic entropy as a measure of functional diversity based on multiple traits. Journal of Vegetation Science 16:533-540.

Braccia, A., and D. Batzer. 2001. Invertebrates associated with woody debris in a southeastern U.S. forested floodplain wetland. Wetlands 21:18-31.

Bray, J. R., and J. T. Curtis. 1957. An ordination of the upland forest communities of southern Wisconsin. Ecological Monographs 27:325-349.

Bucher, V. V. C., S. B. Pointing, K. D. Hyde, and C. A. Reddy. 2004. Production of wood decay enzymes, loss of mass, and lignin solubilization in wood by diverse tropical freshwater fungi. Microbial Ecology 48:331-337.

Casas, J. J., M. O. Gessner, D. Lopez, and E. Descals. 2011. Leaflitter colonisation and breakdown in relation to stream typology: insights from Mediterranean low-order streams. Freshwater Biology 56:2594-2608.

Chevenet, F., S. Dolédec, and D. Chessel. 1994. A fuzzy coding approach for the analysis of long-term ecological data. Freshwater Biology 31:295-309.

Clarke, K. R. 1993. Non-parametric multivariate analyses of changes in community structure. Australian Journal of Ecology 18:117-143.

Collier, K. J., and J. N. Halliday. 2000. Macroinvertebrate-wood associations during decay of plantation pine in New Zealand pumice-bed streams: stable habitat or trophic subsidy? Journal of the North American Benthological Society 19:94-111.

Collier, K. J., and B. J. Smith. 2003. Role of wood in pumicebed streams. II: Breakdown and colonisation. Forest Ecology and Management 177:261-276.

Couch, C. A., and J. L. Meyer. 1992. Development and composition of the epixylic biofilm in a blackwater river. Freshwater Biology 27:43-51.

Cummins, K. W., and M. J. Klug. 1979. Feeding ecology of stream invertebrates. Annual Review of Ecology and Systematics 10:147-172.

De Bello, F., W. Thuiller, J. Lepš, P. Choler, J.-C. Clément, P. Macek, M.-T. Sebastià, and S. Lavorel. 2009. Partitioning of functional diversity reveals the scale and extent of trait convergence and divergence. Journal of Vegetation Science 20: $475-486$. 
Dixon, P. 2003. vegan, a package of $\mathrm{R}$ functions for community ecology. Journal of Vegetation Science 14:927-930.

EA (Environment Agency). 2003. River habitat survey in Britain and Ireland: field survey guidance manual. River habitat survey manual: 2003 version. Environment Agency, Bristol, UK.

Eggert, S. L., and J. B. Wallace. 2007. Wood biofilm as a food resource for stream detritivores. Limnology and Oceanography 52:1239-1245.

Entrekin, S. A., J. L. Tank, E. J. Rosi-Marshall, T. J. Hoellein, and G. A. Lamberti. 2009. Response of secondary production by macroinvertebrates to large wood addition in three Michigan streams. Freshwater Biology 54:1741-1758.

FPL (Forest Products Laboratory) 2010. Wood handbook. Wood as an engineering material. General Technical Report FPLGTR-190. Forest Products Laboratory, US Department of Agriculture Forest Service, Madison, Wisconsin.

Flannigan, M. D., M. A. Krawchuk, W. J. De Groot, B. M. Wotton, and L. M. Gowman. 2009. Implications of changing climate for global wildland fire. International Journal of Wildland Fire 18:483-507.

Gama, M., A. L. Gonçalves, V. Ferreira, M. A. S. Graça, and C. Canhoto. 2007. Decomposition of fire exposed eucalyptus leaves in a Portuguese lowland stream. International Review of Hydrobiology 92:229-241.

Gessner, M. O., E. Chauvet, and M. Dobson. 1999. A perspective on leaf litter breakdown in streams. Oikos 85:377-384.

Golladay, S. W., and R. L. Sinsabaugh. 1991. Biofilm development on leaf and wood surfaces in a boreal river. Freshwater Biology 25:437-450.

Golladay, S. W., and J. R. Webster. 1988. Effects of clear-cut logging on wood breakdown in Appalachian Mountain streams. American Midland Naturalist 119:143-155.

Gonçalves, A. L., A. M. Gama, V. Ferreira, M. A. S. Graça, and C. Canhoto. 2007. The breakdown of blue gum (Eucalyptus globulus Labill.) bark in a Portuguese stream. Fundamental and Applied Limnology 168:307-315.

Graça, M. A. S. 2001. The role of invertebrates on leaf litter decomposition in streams-a review. International Review of Hydrobiology 86:383-393.

Gresswell, R. E. 1999. Fire and aquatic ecosystems in forested biomes of North America. Transactions of the American Fisheries Society 128:193-221.

Gulis, V., V. Ferreira, and M. A. S. Graça. 2006. Stimulation of leaf litter decomposition and associated fungi and invertebrates by moderate eutrophication: implications for stream assessment. Freshwater Biology 51:1655-1669.

Gulis, V., A. D. Rosemond, K. Suberkropp, H. S. Weyers, and J. P. Benstead. 2004. Effects of nutrient enrichment on the decomposition of wood and associated microbial activity in streams. Freshwater Biology 49:1437-1447.

Hall, R. O., G. E. Likens, and H. M. Malcom. 2001. Trophic basis of invertebrate production in 2 streams at the Hubbard Brook Experimental Forest. Journal of the North American Benthological Society 20:432-447.

Harmon, M. E., J. F. Franklin, F. J. Swanson, P. Sollins, S. V. Gregory, J. D. Lattin, N. H. Anderson, S. P. Cline, N. G. Aumen, J. R. Sedell, G. W. Lienkaemper, K. Cromack, K. W. Cummins, A. MacFadyen, and E. D. Ford. 1986. Ecology of coarse woody debris in temperate ecosystems. Advances in Ecological Research 15:133-302.

Hax, C. L., and S. W. Golladay. 1993. Macroinvertebrate colonization and biofilm development on leaves and wood in a boreal river. Freshwater Biology 29:79-87.

Hilderbrand, R. H., A. D. Lemly, C. A. Dolloff, and K. L. Harpster. 1997. Effects of large woody debris placement on stream channels and benthic macroinvertebrates. Canadian Journal of Fisheries and Aquatic Sciences 54:931-939.

Hoffmann, A., and D. Hering. 2000. Wood-associated macroinvertebrate fauna in central European streams. International Review of Hydrobiology 85:25-48.

Hyde, J. C., A. M. S. Smith, R. D. Ottmar, E. C. Alvarado, and P. Morgan. 2011. The combustion of sound and rotten coarse woody debris: a review. International Journal of Wildland Fire 20:163-174.

INAG (Portuguese National Water Authority). 2008. Typology of rivers in Portugal for the implementation of the European Water Framework Directive: I. Abiotic characterization. Ministry of the Environment, Spatial Planning and Regional Development, Portuguese National Water Authority, Lisbon, Portugal (in Portuguese).

IUSS (International Union of Soil Sciences). 2006. World reference base for soil resources. World Soil Resources Reports No. 103. $2^{\text {nd }}$ edition. Food and Agriculture Organization of the United Nations, Rome, Italy.

Johnson, L. B., D. H. Breneman, and C. Richards. 2003. Macroinvertebrate community structure and function associated with large wood in low gradient streams. River Research and Applications 19:199-218.

Jones, T. A., and L. D. Daniels. 2008. Dynamics of large woody debris in small streams disturbed by the 2001 Dogrib fire in the Alberta foothills. Forest Ecology and Management 256: 1751-1759.

Kaller, M. D., and W. E. Kelso. 2006. Short-term decompositional state does not influence use of wood by macroinvertebrates in subtropical, coastal plain streams. Hydrobiologia 571:157-167.

Kaller, M. D., and W. E. Kelso. 2007. Association of macroinvertebrate assemblages with dissolved oxygen concentration and wood surface area in selected subtropical streams of the southeastern USA. Aquatic Ecology 41:95-110.

Lavorel, S., K. Grigulis, S. McIntyre, N. S. G. Williams, D. Garden, J. Dorrough, S. Berman, F. Quétier, A. Thébault, and A. Bonis. 2008. Assessing functional diversity in the fieldmethodology matters! Functional Ecology 22:134-147.

Legendre, P., and M. J. Anderson. 1999. Distance-based redundancy analysis: testing multispecies responses in multifactorial ecological experiments. Ecological Monographs 69:1-24.

Lemly, A. D., and R. H. Hilderbrand. 2000. Influence of large woody debris on stream insect communities and benthic detritus. Hydrobiologia 421:179-185.

Lepš, J., F. D. Bello, S. Lavorel, and S. Berman. 2006. Quantifying and interpreting functional diversity of natural communities: practical considerations matter. Preslia 78:481-501.

Lock, M. A., R. L. Wallace, J. W. Costerton, R. M. Ventullo, and S. E. Charlton. 1984. River epilithon: toward a structuralfunctional model. Oikos 42:10-22.

Lyon, J. P., S. J. Nicol, J. A. Lieschke, and D. S. L. Ramsey. 2009. Does wood type influence the colonisation of this habitat by 
macroinvertebrates in large lowland rivers? Marine and Freshwater Research 60:384-393.

Magoulick, D. D. 1998. Effect of wood hardness, condition, texture and substrate type on community structure of stream invertebrates. American Midland Naturalist 139:187-200.

Malison, R. L., and C. V. Baxter. 2010. Effects of wildfire of varying severity on benthic stream insect assemblages and emergence. Journal of the North American Benthological Society 29:1324-1338.

Mathooko, J. M., and C. O. Otieno. 2002. Does surface textural complexity of woody debris in lotic ecosystems influence their colonization by aquatic invertebrates? Hydrobiologia 489: $11-20$.

McArdle, B. H., and M. J. Anderson. 2001. Fitting multivariate models to community data: a comment on distance-based redundancy analysis. Ecology 82:290-297.

McLachlan, A. J. 1970. Submerged trees as a substrate for benthic fauna in the recently created Lake Kariba (Central Africa). Journal of Applied Ecology 7:253-266.

Mihuc, T. B., and G. W. Minshall. 1995. Trophic generalists vs. trophic specialists: implications for food web dynamics in post-fire streams. Ecology 76:2361-2372.

Minshall, G. W. 2003. Responses of stream benthic macroinvertebrates to fire. Forest Ecology and Management 178: $155-161$.

Minshall, G. W., C. T. Robinson, and D. E. Lawrence. 1997. Postfire responses of lotic ecosystems in Yellowstone National Park, USA. Canadian Journal of Fisheries and Aquatic Sciences 54:2509-2525.

Monk, D. C. 1976. The distribution of cellulase in freshwater invertebrates of different feeding habits. Freshwater Biology 6:471-475.

Moreira, F., O. Viedma, M. Arianoutsou, T. Curt, N. Koutsias, E. Rigolot, A. Barbati, P. Corona, P. Vaz, G. Xanthopoulos, F. Mouillot, and E. Bilgili. 2011. Landscape-wildfire interactions in southern Europe: implications for landscape management. Journal of Environmental Management 92:2389-2402.

Moriondo, M., P. Good, R. Durao, M. Bindi, C. Giannakopoulos, and J. CorteReal. 2006. Potential impact of climate change on fire risk in the Mediterranean area. Climate Research 31: $85-95$.

Nilsen, H. C., and R. W. Larimore. 1973. Establishment of invertebrate communities on log substrates in the Kaskaskia River, Illinois. Ecology 54:366-374.

O'Connor, N. A. 1991. The effects of habitat complexity on the macroinvertebrates colonising wood substrates in a lowland stream. Oecologia (Berlin) 85:504-512.

Oksanen, J., R. Kindt, P. Legendre, B. O'Hara, G. Simpson, P. Solymos, M. Stevens, and H. Wagner. 2012. vegan: community ecology package. $\mathrm{R}$ package version 2.0-5. R Project for Statistical Computing, Vienna, Austria. (Available from: http:// CRAN.R-project.org/package $=$ vegan)

Oliver, A., M. Bogan, D. Herbst, and R. Dahlgren. 2012. Shortterm changes in-stream macroinvertebrate communities following a severe fire in the Lake Tahoe basin, California. Hydrobiologia 694:117-130.

Oscoz, J., D. Galicia, and R. Miranda. 2011. Identification guide of freshwater macroinvertebrates of Spain. Springer, Dordrecht, The Netherlands.
Pereira, C. R. D., N. H. Anderson, and T. Dudley. 1982. Gut content analysis of aquatic insects from wood substrates. Melanderia 39:23-33.

Phillips, E. C., and R. V. Kilambi. 1994. Use of coarse woody debris by Diptera in Ozark streams, Arkansas. Journal of the North American Benthological Society 13:151-159.

Pinheiro, J., D. Bates, S. DebRoy, D. Sarkar, and the R Development Core Team. 2012. nlme: linear and nonlinear mixed effects models. $\mathrm{R}$ package version 3.1-104. R Project for Scientific Computing, Vienna, Austria.

Pitt, D. B., and D. P. Batzer. 2011. Woody debris as a resource for aquatic macroinvertebrates in stream and river habitats of the southeastern united states: a review. In Proceedings of the 2011 Georgia Water Resources Conference. April 1114. University of Georgia, Athens, Georgia.

Raven, P., N. Holmes, J. Pádua, J. Ferreira, S. Hughes, L. Baker, L. Taylor, and K. Seager. 2009. River habitat survey in southern Portugal. Results from 2009. Environment Agency, Bristol, UK. (Available from: www.riverhabitatsurvey.org/? page_id=49)

Resh, V. H., A. V. Brown, A. P. Covich, M. E. Gurtz, H. W. Li, G. W. Minshall, S. R. Reice, A. L. Sheldon, J. B. Wallace, and R. C. Wissmar. 1988. The role of disturbance in stream ecology. Journal of the North American Benthological Society $7: 433-455$.

Robinson, C. T., U. Uehlinger, and G. W. Minshall. 2005. Functional characteristics of wilderness streams twenty years following wildfire. Western North American Naturalist 65:1-10.

Romme, W., M. Boyce, R. Gresswell, E. Merrill, G. Minshall, C. Whitlock, and M. Turner. 2011. Twenty years after the 1988 Yellowstone fires: lessons about disturbance and ecosystems. Ecosystems 14:1196-1215.

Sakai, K. 2001. Chemistry of bark. Pages 243-273 in D. N.-S. Hon and N. Shiraishi (editors). Wood and cellulosic chemistry. Marcel Dekker, New York.

Schniewind, A. P. 1989. Concise encyclopedia of wood and wood-based materials. Pergamon Press, New York.

Spänhoff, B., C. Alecke, and E. I. Meyer. 2000. Colonization of submerged twigs and branches of different wood genera by aquatic macroinvertebrates. International Review of Hydrobiology 85:49-66.

Spänhoff, B., and M. O. Gessner. 2004. Slow initial decomposition and fungal colonization of pine branches in a nutrientrich lowland stream. Canadian Journal of Fisheries and Aquatic Sciences 61:2007-2013.

Spänhoff, B., C. Reuter, and E. I. Meyer. 2006. Epixylic biofilm and invertebrate colonization on submerged pine branches in a regulated lowland stream. Archiv für Hydrobiologie 165: 515-536.

Strahler, A. 1957. Quantitative analysis of watershed geomorphology. Transactions of the American Geophysical Union 38: 913-920.

Tachet, H., P. Richoux, M. Bournaud, and P. Usseglio-Polatera. 2010. Invertébrés d'eau douce: systématique, biologie, écologie. CNRS Editions, Paris, France.

Tank, J. L., E. J. Rosi-Marshall, N. A. Griffiths, S. A. Entrekin, and M. L. Stephen. 2010. A review of allochthonous organic matter dynamics and metabolism in streams. Journal of the North American Benthological Society 29:118-146. 
Testa, S., F. D. Shields, and C. M. Cooper. 2011. Macroinvertebrate response to stream restoration by large wood addition. Ecohydrology 4:631-643.

Usseglio-Polatera, P. 1991. Graphical expression of the ecological significance of a faunal community, and its application to the study of the Rhone River macroinvertebrates at Lyon. Bulletin d'Ecologie 22:195-202 (in French).

Usseglio-Polatera, P., M. Bournaud, P. Richoux, and H. Tachet. 2000. Biological and ecological traits of benthic freshwater macroinvertebrates: relationships and definition of groups with similar traits. Freshwater Biology 43:175-205.

Vaz, P. G., E. C. Merten, D. R. Warren, C. T. Robinson, P. Pinto, and F. C. Rego. 2013a. Which stream wood becomes functional following wildfires? Ecological Engineering 54: 82-89.

Vaz, P. G., D. R. Warren, E. C. Merten, C. Robinson, P. Pinto, and F. C. Rego. 2013b. Effects of forest type and stream size on volume and distribution of stream wood: legacies of wildfire in a Euro-Mediterranean context. Freshwater Science 32: 126-141.

Vaz, P. G., D. R. Warren, P. Pinto, E. C. Merten, C. Robinson, and F. C. Rego. 2011. Tree type and forest management effects on the structure of stream wood following wildfires. Forest Ecology and Management 262:561-570.

Verkaik, I., M. Rieradevall, S. Cooper, J. Melack, T. Dudley, and N. Prat. 2013. Fire as a disturbance in Mediterranean climate streams. Hydrobiologia (in press). doi:10.1007/s10750-0131463-3

Vieira, N. K. M., W. H. Clements, L. S. Guevara, and B. F. Jacobs. 2004. Resistance and resilience of stream insect communities to repeated hydrologic disturbances after a wildfire. Freshwater Biology 49:1243-1259.
Wallace, J. B., S. L. Eggert, J. L. Meyer, and J. R. Webster. 1997. Multiple trophic levels of a forest stream linked to terrestrial litter inputs. Science 277:102-104.

Wallace, J. B., J. R. Webster, and J. L. Meyer. 1995. Influence of log additions on physical and biotic characteristics of a mountain stream. Canadian Journal of Fisheries and Aquatic Sciences 52:2120-2137.

Warren, D., and C. Kraft. 2006. Invertebrate community and stream substrate responses to woody debris removal from an ice storm-impacted stream system, NY, USA. Hydrobiologia 568:477-488.

Winterbourn, M. J. 1982. The invertebrate fauna of a forest stream and its association with fine particulate matter. New Zealand Journal of Marine and Freshwater Research 16:271-281.

Wong, M. M., T.-K. Goh, I. J. Hodgkiss, K. Hyde, V. M. Ranghoo, C. M. Tsui, W.-H. Ho, W. W. Wong, and T.-K. Yuen. 1998. Role of fungi in freshwater ecosystems. Biodiversity and Conservation 7:1187-1206.

Wooster, D. E., S. W. Miller, and S. J. Debano. 2012. An examination of the impact of multiple disturbances on a river system: taxonomic metrics versus biological traits. River Research and Applications 28:1630-1643.

Zare-Maivan, H., and C. A. Shearer. 1988. Extracellular enzyme production and cell wall degradation by freshwater lignicolous fungi. Mycologia 80:365-375.

Zelt, R. B., and E. E. Wohl. 2004. Channel and woody debris characteristics in adjacent burned and unburned watersheds a decade after wildfire, Park County, Wyoming. Geomorphology 57:217-233.

Zuur, A. F., E. N. Ieno, N. Walker, A. A. Saveliev, and G. M. Smith. 2009. Mixed effects models and extensions in ecology with R. Springer, New York. 